\title{
Hematologic manifestations of SARS-CoV-2 infection and MIS-C in hospitalized children. Results of the PICNIC registry.
}

Sarah Tehseen ${ }^{1}$, Suzan Williams ${ }^{2}$, Joan Robinson ${ }^{3}$, Shaun Morris ${ }^{2}$, Tala Tal ${ }^{2}$, Ari Bitnun ${ }^{2}$, Peter Gill ${ }^{2}$, Ann Yeh ${ }^{2}$, Carmen Yea ${ }^{4}$, Helena Brenes ${ }^{5}$, Adrianna Yock-Corrales ${ }^{5}$, Rolando Nuevo $^{5}$, Gabriela Ivankovich-Esctoto ${ }^{5}$, Alejandra Fallas ${ }^{5}$, Jesse Papenburg ${ }^{6}$, Marie-Astrid Lefebvre $^{6}$, Rosie Scuccimarri ${ }^{6}$, Alireza Nateghian ${ }^{7}$, Behzad Aski ${ }^{7}$, Rachel Dwilow ${ }^{8}$, Jared Bullard $^{8}$, Leo Restivo ${ }^{9}$, Suzette Cooke ${ }^{9}$, Alison Lopez ${ }^{10}$, Ashley Roberts ${ }^{10}$, Manish Sadarangani $^{11}$, Michelle Barton Forbes ${ }^{12}$, Nicole Saux ${ }^{13}$, Jennifer Bowes ${ }^{13}$, Rupeena Purewal $^{1}$, Janell Lautermilch ${ }^{14}$, Ann Bayliss ${ }^{15}$, Jacqueline Wong ${ }^{16}$, Kirk Leifso ${ }^{17}$, Cheryl Foo $^{18}$, Luc Panetta ${ }^{19}$, Fatima Kakkar ${ }^{19}$, Dominique Piche ${ }^{20}$, Isabelle Viel-Theriault ${ }^{21}$, Joanna Merckx ${ }^{22}$, and Lani Lieberman ${ }^{23}$

${ }^{1}$ University of Saskatchewan

${ }^{2}$ The Hospital for Sick Children

${ }^{3}$ University of Alberta

${ }^{4}$ SickKids Research Institute

${ }^{5}$ Hospital Nacional de Ninos Dr Carlos Saenz Herrera

${ }^{6}$ McGill University Faculty of Medicine

${ }^{7}$ Iran University of Medical Sciences

${ }^{8}$ University of Manitoba Faculty of Health Sciences

${ }^{9}$ University of Calgary Faculty of Medicine

${ }^{10}$ The University of British Columbia Faculty of Medicine

${ }^{11}$ BC Children's Hospital Research Institute

${ }^{12}$ London Health Sciences Centre Children's Hospital

${ }^{13}$ University of Ottawa Faculty of Medicine

${ }^{14}$ University of Saskatchewan College of Medicine

${ }^{15}$ Trillium Health Partners

${ }^{16}$ McMaster University Faculty of Health Sciences

${ }^{17}$ Queen's University

${ }^{18}$ Memorial University of Newfoundland

${ }^{19}$ University of Montreal Faculty of Medicine

${ }^{20}$ Dalhousie University Faculty of Medicine

${ }^{21}$ Laval University Faculty of Medicine

${ }^{22} \mathrm{McGill}$ University Faculty of Medicine and Health Sciences

${ }^{23}$ University Health Network

January 12, 2022 


\begin{abstract}
Introduction: Hematologic complications of SARS-CoV-2 infection are well described in hospitalized adults with correlation to adverse outcomes. Information published in children has been limited. Methods: An international multi-centered retrospective registry was established to collect data on the clinical manifestations of SARS-CoV-2 or multisystem inflammatory syndrome (MIS-C) in hospitalized children between February 1, 2020 - May 31, 2021. This sub-study focused on hematologic manifestations. Study variables included patient demographics, comorbidities, clinical presentation, course, laboratory parameters, management, and outcomes. Results: Nine hundred and eighty-five children were enrolled and 915 (93\%) had clinical information available; 385 (42\%) had symptomatic SARS-CoV-2 infection upon admission, 288 had MIS-C (31.4\%) and 242 (26.4\%) had alternate diagnosis with SARS-CoV-2 identified incidentally. During hospitalization, 10 children (1\%) experienced a thrombotic event, $16(1.7 \%)$ had hemorrhage and $2(0.2 \%)$ had both thrombotic and hemorrhagic episodes. Significant prothrombotic comorbidities included congenital heart disease $(p$-value $=0.007)$, central venous catheter $(p=0.04)$ in children with primary SARS-CoV-2 infection; and obesity ( $p$-value $=0.002)$, cytokine storm $(p=0.012)$ in those with MIS-C. Significant prohemorrhagic conditions included age $>10$ years $(\mathrm{p}=0.04)$, CVC $(\mathrm{p}=0.03)$ in children with primary SARS-CoV-2infection; and thrombocytopenia (0.001), cytokine storm (0.02) in those with MIS-C. Eleven patients died (1.2\%) with no deaths attributed to thrombosis or hemorrhage Conclusion: Thrombotic and hemorrhagic complications are uncommon in children with SARSCoV-2 infection and observed with underlying co-morbid conditions. Understanding the complete spectrum of hematologic complications in children with SARS-CoV-2 infection or MIS-C requires ongoing multi-center studies.
\end{abstract}

\title{
Hosted file
}

Hematologic_manifestations_in_SARS-CoV-2SUBMIT_PBC_040122.docx available at https: //authorea.com/users/455028/articles/552482-hematologic-manifestations-of-sars-cov-2infection-and-mis-c-in-hospitalized-children-results-of-the-picnic-registry

\section{Hosted file}

Table 1_PBC12252021.docx available at https://authorea.com/users/455028/articles/552482hematologic-manifestations-of-sars-cov-2-infection-and-mis-c-in-hospitalized-childrenresults-of-the-picnic-registry

\section{Hosted file}

Table 2_PBC12252021.docx available at https://authorea.com/users/455028/articles/552482hematologic-manifestations-of-sars-cov-2-infection-and-mis-c-in-hospitalized-childrenresults-of-the-picnic-registry

\section{Hosted file}

Table 3_PBC25122021.docx available at https://authorea.com/users/455028/articles/552482hematologic-manifestations-of-sars-cov-2-infection-and-mis-c-in-hospitalized-childrenresults-of-the-picnic-registry

\section{Hosted file}

Table 4_PBC25122021.docx available at https://authorea.com/users/455028/articles/552482hematologic-manifestations-of-sars-cov-2-infection-and-mis-c-in-hospitalized-childrenresults-of-the-picnic-registry

\section{Hosted file}

Table 5_PBC12252021.docx available at https://authorea.com/users/455028/articles/552482hematologic-manifestations-of-sars-cov-2-infection-and-mis-c-in-hospitalized-childrenresults-of-the-picnic-registry

\section{Hosted file}


Table 6_PBC12252021.docx available at https://authorea.com/users/455028/articles/552482hematologic-manifestations-of-sars-cov-2-infection-and-mis-c-in-hospitalized-childrenresults-of-the-picnic-registry 